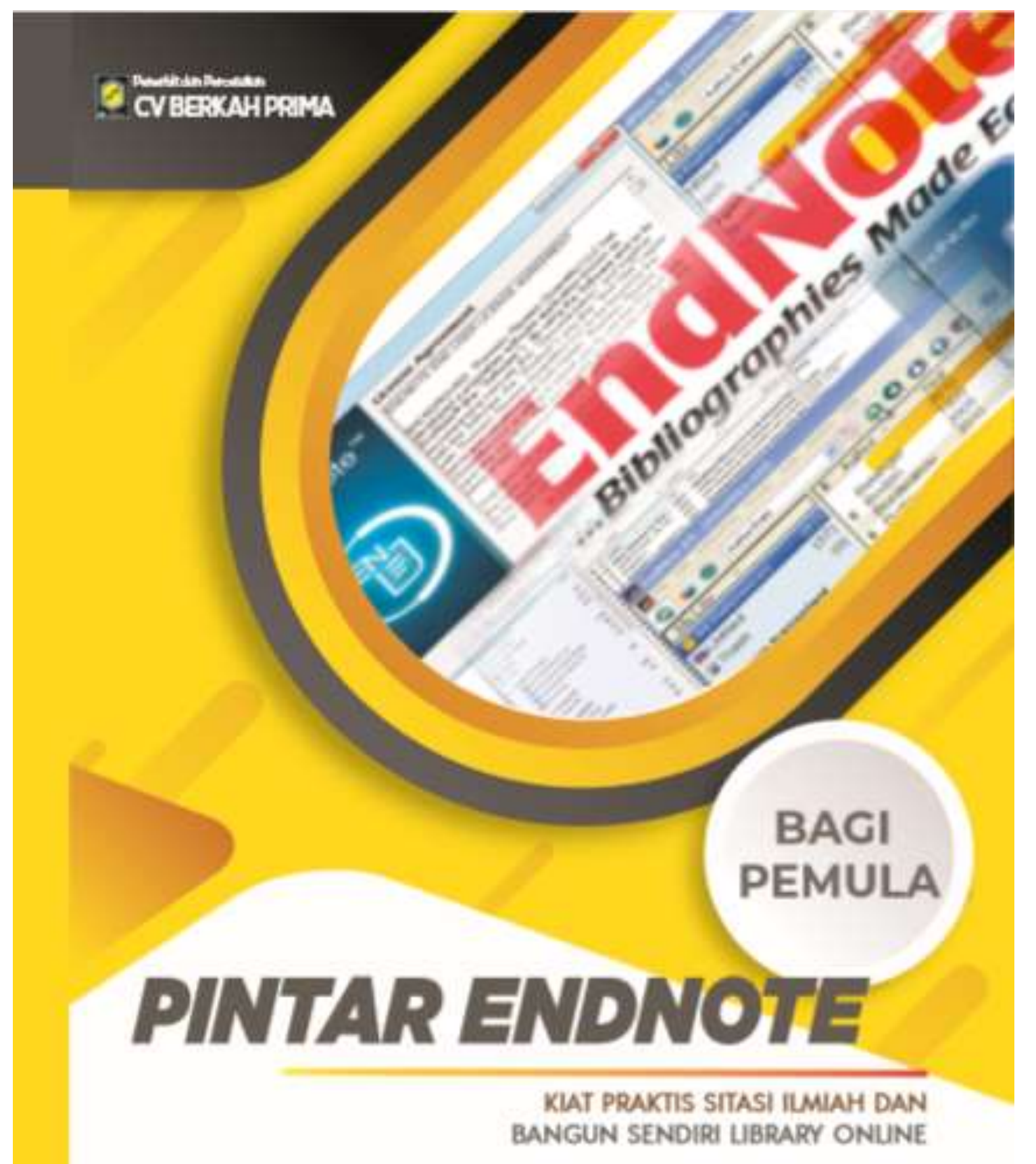

Dr. Rahadian Zainul, S.Pd, MSI. ACt 


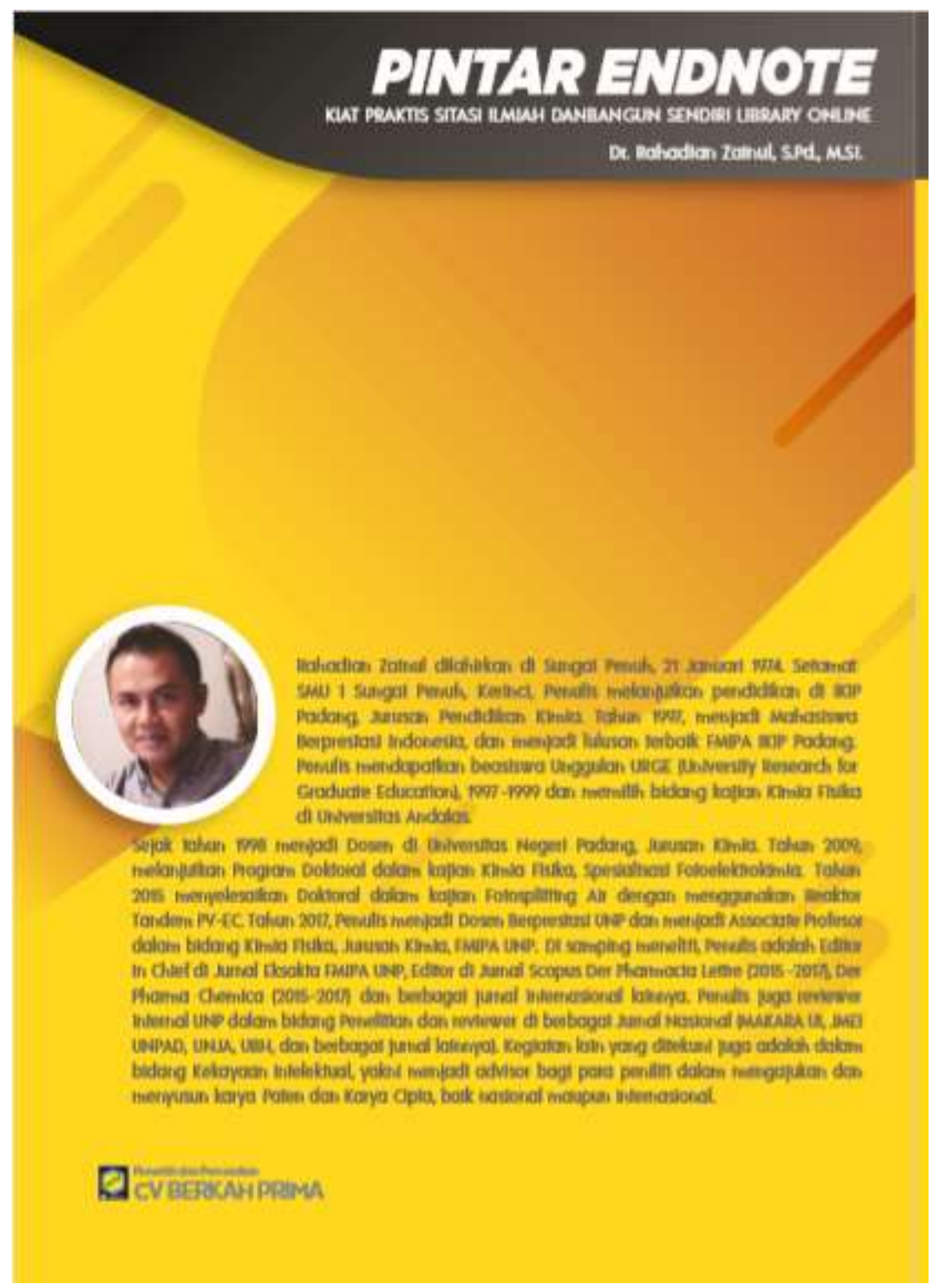




\section{PINTAR ENDNOTE : \\ KIAT PRAKTIS SITASI ILMIAH DAN \\ BANGUN SENDIRI LIBRARY ONLINE}




\section{UNDANG-UNDANG REPUBLIK INDONESIA}

NO 19 TAHUN 2002

TENTANG HAK CIPTA

PASAL 72

KETENTUAN PIDANA

SAKSI PELANGGARAN

1. Barangsiapa dengan sengaja dan tanpa hak mengumumkan atau memperbanyak suatu Ciptaan atau memberi izin untuk itu, dipidana dengan pidana penjara paling singkat 1 ( satu) bulan dan/atau denda paling sedikit Rp 1.000.000,00 (satu juta rupiah), atau pidana penjara paling lama 7 (tujuh) tahun dan/atau denda paling banyak Rp. 5.000.000.000,00 (lima milyar rupiah)

2. Barangsiapa dengan sengaja menyerahkan, menyiarkan, memamerkan, mengedarkan, atau menjual kepada umum suatu Ciptaan atau barang hasil pelanggaran Hak Cipta atau Hak

Terkait sebagaimana dimaksud dalam ayat (1), dipidana dengan pidana penjara paling lama 5 (lima) tahun dan/atau denda

paling banyak Rp 500.000.000,00 (lima ratus juta rupiah). 


\section{PINTAR ENDNOTE : KIAT PRAKTIS SITASI ILMIAH DAN BANGUN SENDIRI LIBRARY ONLINE}

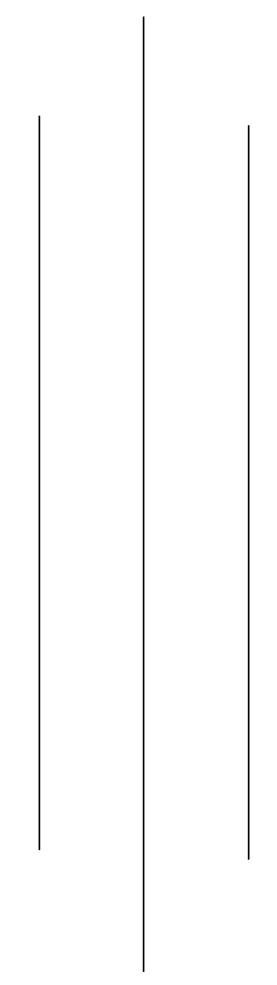

Dr. Rahadian Zainul, S.Pd., M.Si. 


\section{PINTAR ENDNOTE : KIAT PRAKTIS SITASI ILMIAH DAN BANGUN SENDIRI LIBRARY ONLINE}

Penulis :

Dr. Rahadian Zainul, S.Pd., M.Si.

Editor :

Dr. Desy Kurniawati, M.Si. (Editor)

ISBN : 9-786025-088179

CV. BERKAH PRIMA

Alamat: Jalan Datuk Perpatih Nan Sabatang 287, Air Mati, Solok

Sumatera Barat.

Anggota IKAPI Pusat

No. Anggota : 016/SBA/18 tanggal I Agustus 2018

Cetakan Pertama, Oktober 2017 
Hak Cipta dilindungi oleh undang-undang.

Dilarang memperbanyak atau memindahkan sebagian atau seluruh isi buku ini dalam bentuk apapun. Secara elektronis maupun mekanis, termasuk memfotocopy, merekam, atau dengan teknik perekaman lainnya, tanpa izin tertulis dari penerbit

Tajuk entri utama : Rahadian,

\section{PINTAR ENDNOTE :}

KIAT PRAKTIS SITASI ILMIAH DAN BANGUN SENDIRI LIBRARY ONLINE

Edisi Pertama, cet. Ke-I Padang: Berkah Prima, 2018

Editor : Tim editor ( Desy Kurniawati )

I (satu) jilid; |4,8x2 I cm (A5), Isi 170 hal. + (xviii )

ISBN:

Editor isi (Substansi): Dr. Desy Kurniawati, M.Si.

Editor Bahasa: Dr.Nasbahry Couto, M.Sn..

Desainer Grafis : Annisa Awalliyah

Perwajahan: Tim Layout CV. Berkah Prima 


\section{KATA PENGANTAR}

Alhamdulillah, buku berjudul PINTAR ENDNOTE : KIAT PRAKTIS SITASI ILMIAH DAN BANGUN SENDIRI LIBRARY ONLINE telah berhasil disusun. Semoga buku ini dapat bermanfaat dalam pengembangan ilmu pengetahuan, khususnya dalam bidang Sain dan Lietrasi.

Buku PINTAR ENDNOTE : KIAT PRAKTIS SITASI ILMIAH DAN BANGUN SENDIRI LIBRARY ONLINE ini, dapat digunakan oleh Mahasiswa dan Peneliti yang tertarik dalam pengembangan Literasi. Dalam buku ini ada dasar pembuatan Library Online dan panduan untuk melakukan studi review dan penyusunan karya ilmiah yang bertaraf internasional. Dalam buku ini, pembaca dapat menggunakannya untuk kajian dalam mengakses berbagai literatur di seluruh perpustakaan dunia. Salah satunya adalah Pubmed di Amerika Serikat yang memiliki manuscript lebih kurang 26 juta.

Buku ini dikembangkan dari pelaksanaan pengabdian kepada masyarakat yang dilakukan di berbagai sekolah di Sumatera Barat, salah satunya adalah di SMU Negeri 2 Padangpanjang selama bulan Oktober 2018. Kegiatan ini bertujuan untuk menghasilkan berbagai karya ilmiah dari Guru guru MGMP Kimia se Kota Padangpanjang.

Kegiatan pengabdian ini dilakukan bersama dengan Tim Pengabdian, yakni Budhi Oktavia, Ph.D., Edi Nasra, M.Si dan Tim Mahasiswa, Visca, Yulia dan Trihanto. Kegiatan ini terlaksana berkat dukungan dan bantuan dari Lembaga Penelitian dan Pengabdian Masyarakat Universitas Negeri Padang.

Akhirulkalam, terima kasih dan semoga bermanfaat.

Juni 2017

Dr. Rahadian Zainul, S.Pd., M.Si. 


\section{RINGKASAN}

Dalam penulisan karya ilmiah diperlukan satu sistem kerja secara online (daring) sehingga proses penelusuran berlangsung cepat dan akurat. Model penulisan berbasis online data dengan aplikasi endnote merupakan salah satu alternatif model penulisan karya ilmiah yang dapat diterapkan pada guru guru sekolah dan dosen. Tujuan penelitian ini adalah mengembangkan model penulisan karya ilmiah dan mengukur efektifitas penerapannya pada para guru-guru MGMP Kimia di Kota Padang Panjang. Metode yang digunakan adalah pengembangan model ADDIE dan Uji keberhasilan dengan statistik CV (Coeficient of Variations). Penerapan dilakukan pada seluruh guru guru Kimia yang tergabung dalam MGMP Kimia Kota Padangpanjang. Setiap guru akan mendapatkan pelatihan dan pendampingan dalam membuat Library Online sebagai basis data. Pelatihan dilanjutkan dengan pengaplikasian pada penyusunan karya ilmiah yang berdasarkan pada data data hasil belajar siswa di sekolah masing masing. Dari hasil penelitian diperoleh tingkat kemudahan dalam literasi dan penyusunan karya ilmiah mencapai $70 \%$ SS dan 30\% S. Tingkat ketertarikan Guru dalam menyusun karya ilmiah dengan Endnote mencapai 30\%. SS san 70\% S. Keinginan peserta untuk memulai menyusun karya ilmiah mencapai $20 \%$ AS, $60 \%$ S dan $20 \%$ SS . Pada Uji efektivitas pelatihan diperoleh koefisien variasi mengalami penurunan dari $2.75 \%$ menjadi $1.63 \%$, sehingga dapat disimpulkan model penyusunan karya ilmiah dengan endnote berhasil diterapkan bagi Guru-guru MGMP Kimia Kota Padangpanjang.

Keywords : Model, ADIE, Endnote, Kimia, MGMP, Padangpanjang

\section{PENDAHULUAN}

Literasi adalah kemampuan untuk membaca, menulis, dan menggunakan aritmatika. Lebih luas, literasi untuk mencakup kemampuan untuk menggunakan bahasa, angka, gambar, komputer, dan sarana dasar lainnya untuk memahami, berkomunikasi, memperoleh ilmu yang bermanfaat. Konsep literasi berkembang memasukkan keterampilan untuk mengakses pengetahuan melalui teknologi dan kemampuan untuk menilai konteks yang kompleks.

Kunci untuk literasi adalah kemampuan membaca yakni keterampilan yang diawali dengan kemampuan untuk menterjemahkan kalimat (kata-kata), menulis kembali kalimat (kata-kata) tersebut, dan akhirnya memahami konsep. "Membaca", berarti mengetahui bunyi (fonologi), pola ejaan (ortografi), arti kata (semantik), tata bahasa (sintaks) dan pola pembentukan kata (morfologi). Dari proses inilah orientasi, eksplorasi, pembentukan konsep (pemahaman) dan aplikasi dapat terbentuk.

Setelah keterampilan ini diperoleh, mahasiswa dapat menghasilkan karya yang kritis (analisis), membuat kesimpulan (sintesis); menulis dengan akurasi (koherensi); dan untuk menggunakan informasi dan wawasan dari teks sebagai dasar untuk keputusan dan pemikiran kreatif.

UNESCO mendefinisikan Literasi sebagai "kemampuan untuk mengidentifikasi, memahami, menafsirkan, membuat, berkomunikasi dan menghitung, menggunakan dan menulis bahan yang terkait dengan konteks yang berbeda-beda. Literasi melibatkan kontinum belajar dalam memungkinkan individu untuk mencapai tujuan mereka, untuk mengembangkan pengetahuan dan potensi mereka, dan untuk berpartisipasi penuh dalam komunitas mereka dan masyarakat yang lebih luas".

Literasi informasi merupakan kemampuan yang sangat diperlukan dalam memenuhi kebutuhan seseorang. Dalam memenuhi kebutuhan tersebut terdapat beberapa kriteria dalam literasi informasi. Menurut Pendit (2007:7) bahwa terdapat 7 (tujuh) keterampilan yang dibutuhkan dalam era digital yaitu Tool literacy: kemampuan memahami dan menggunakan teknologi informasi secara konseptual dan praktikal, termasuk di dalamnya kemampuan menggunakan perangkat lunak, keras, multimedia yang 
relevan dengan bidang kerja atau studi. Resources literacy;: kemampuan memahami bentuk, format, lokasi, dan cara mendapatkan sumber daya informasi terutama jaringan informasi yang terus berkembang

Social structural literacy; Pemahaman tentang bagaimana informasi dihasilkan oleh berbagai pihak di dalam sebuah masyarakat. Research literacy; Kemampuan menggunakan peralatan berbasis teknologi informasi sebagai alat riset. Publishing literacy; Kemampuan untuk menyusun dan menerbitkan publikasi dan ide ilmiah ke kalangan masyarakat dengan memanfaatkan komputer dan internet.

Emerging technology literacy ; Kemampuan yang memungkinkan seseorang untuk terus menerus menyesuaikan diri dan mengikuti perkembangan tekhnologi dan bersama-sama dengan komunitasnya ikut menentukan arah pemanfaatan tekhnologi informasi untuk kepentingan pengembangan ilmu. Critical literacy ; Kemampuan melakukan evaluasi secara kritis terhadap untung rugi menggunakan teknologi telematika dalam kegiatan ilmiah.

Dalam artikel ini, bagaimana menggunakan menggunakan endnote, dan aplikasi pembantu (google) untuk mengorganisasi bahan bahan dan informasi yang ada untuk mendapatkan ide ide ilmiah serta mengembangkannya menjadi produk literasi sains dan kreatif, baik dalam bentuk teknologi maupun publikasi ilmiah.

\section{EKPERIMENTAL}

\section{BAHAN DAN PROSEDURAL}

Software yang digunakan Endnote X7 Thomson Reuters Aplikasi ini diinstalkan pada Windows XP atau Vista, Windows 8, yang lebih ringan dan biasanya berjalan dengan baik untuk beberapa aplikasi. Pada Windows terbaru, Windows 8 dan 10, beberapa aplikasi membutuhkan versi update dan lebih berat untuk dijalankan.

Perancangan model penyusunan dilakukan dengan metode ADDIE. Model ADDIE merupakan singkatan dari Analyze, Design, Develop or, Implement and Evaluation (Khoe Yao Tung: 2016). Model ADDIE dikembangkan oleh Dick and Carry (1996) untuk merancang sistem pembelajaran. Model ADDIE terdiri atas 5 tahap kegiatan, yaitu : analyze, design, develop, implement, dan evaluation. Skema rancangan ini dapat dilihat pada Gambar 1.

Prosedur yang dilakukan adalah instalasi dan koneksi jaringan internet sehingga memungkinkannya 'surfing' data berjalan lebih cepat. Proses instalasi dilakukan dengan cara membuka file aplikasi (EXE) dan seterusnya mengikuti proses instalasi sebagaimana biasanya, yakni tekan NEXT dan pilih sesuai petunjuk dan perintahnya. Apabila proses instalasi selesai, maka software atau aplikasi sudah bisa dijalankan.. 


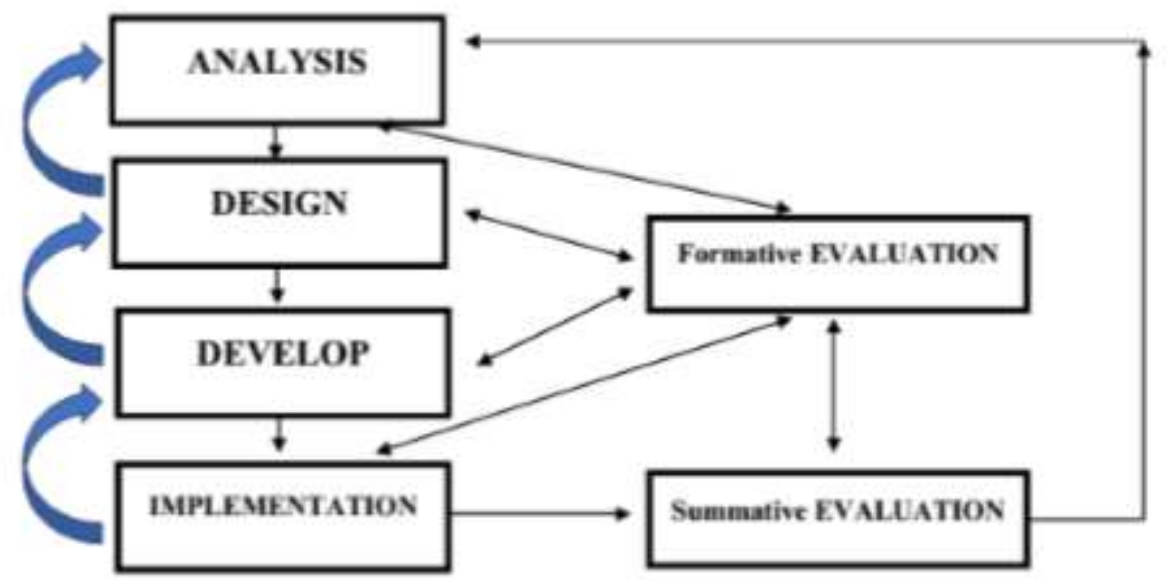

Gambar 1. Model ADDIE dan Tahapannya (Khoe Yao Tung, 2016:68)

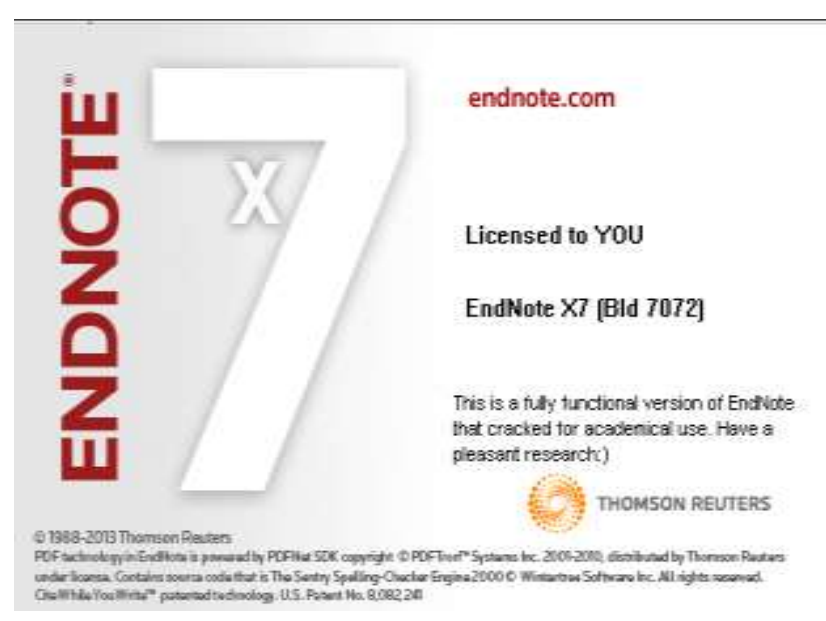

Gambar 2. Tampilan awal software endnote

Setelah instalasi selesai, maka proses literasi sduah dapat dilakukan dengan tahapan awal yakni menjalankan endnote seperti terlihat pada gambar 2.

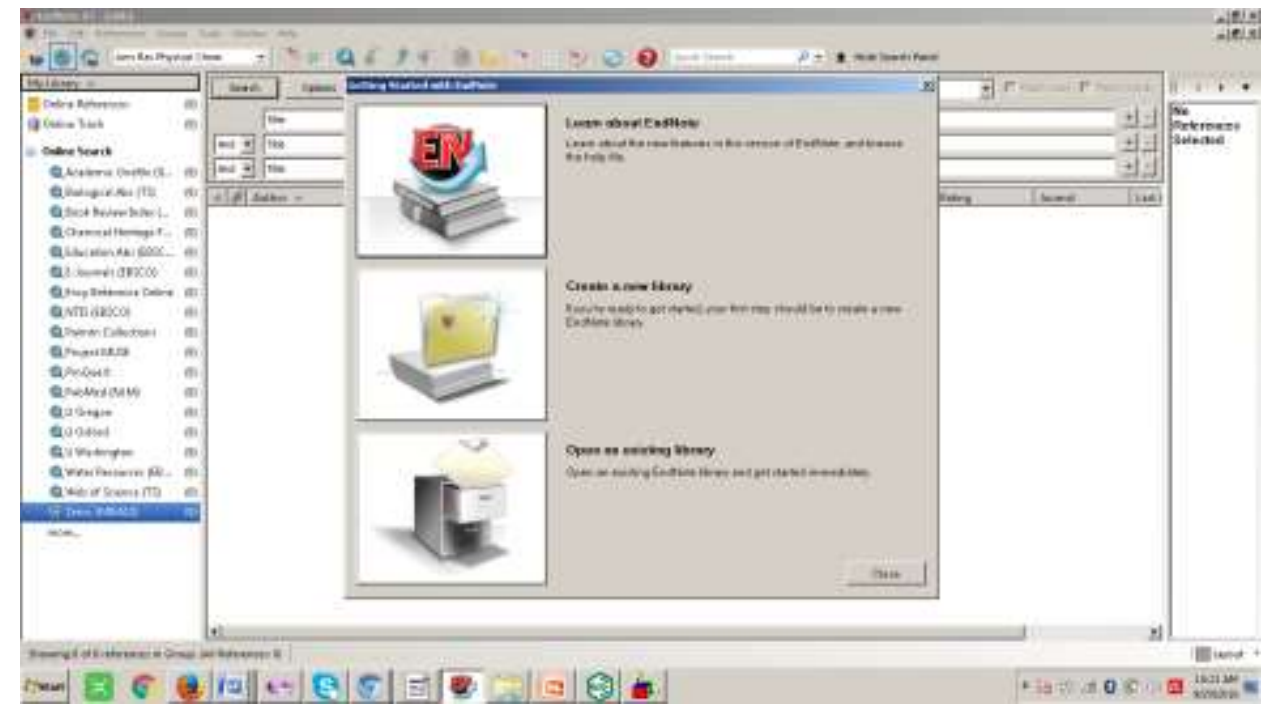


Gambar 3. Program endnote saat dijalankan untuk tujuan literasi

Langkah awal dalam proses literasi adalah memutuskan ide dan persoalan yang akan dibahas melalui kata kunci (keywords). Tanpa keywords, penggunaan internet akan mengambang dan tidak efisien. Dengan penggunaan Endnote X7, proses identifikasi keyword membutuhkan waktu 1 detik, tidak jauh beda dengan menggunakan penjelajah google. Misalnya, pada proses pencarian keyword "BIOLOGY" dengan google cendikia, membutuhkan waktu 0.04 detik dengan jumlah temuan 5.260.000. Sementara, bila menggunakan ENDNOTE X7, memerlukan waktu 0.5 detik dengan temuan 1.347.502 literatur pada Pustaka Dunia PubMed (NLM) seperti terlihat pada gambar 3.

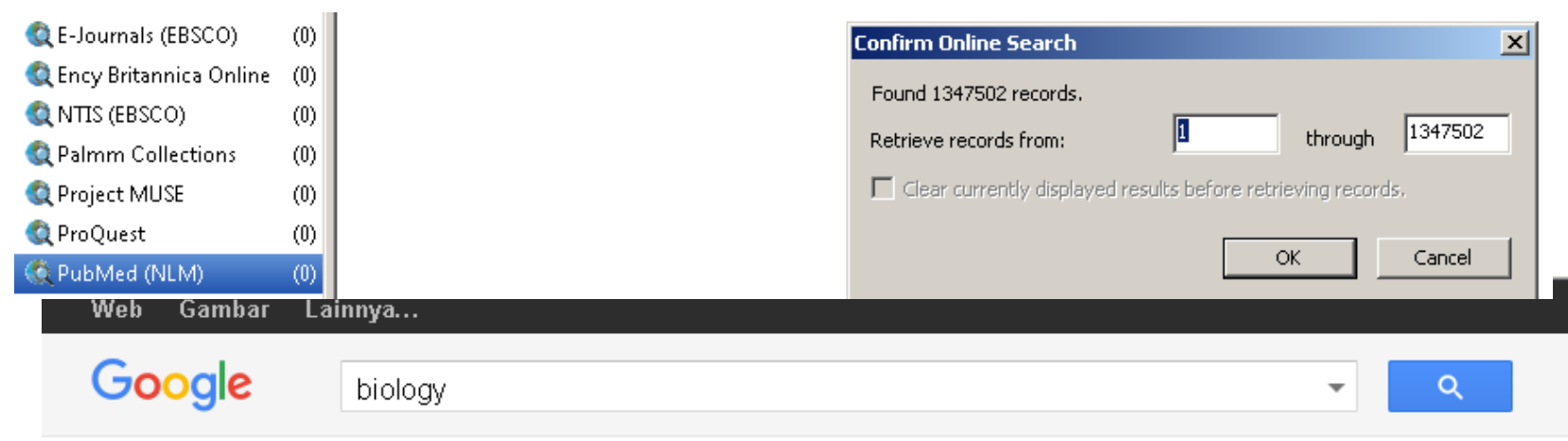

Cendekia Sekitar 5.260.000 hasil (0,04 dtk)

(b) Penjelajahan Endnote X7

Gambar 3. Penjelajahan Google Cendikia dan Endnote 7

Penjelajahan Google Cendikia lebih bersifat umum, sementara penjelajahan menggunakan Endnote7 lebih spesifik. Pada kasus di atas, endnote digunakan untuk menjelajah pada Web Pubmed(NLM) yang menyediakan lebih dari 26 juta citation untuk bidang biomedik, baik berupa jurnal maupun buku. Ada ribuan perpustakaan di dunia yang terintegrasi pada endnote $\mathrm{X} 7$, tetapi tidak semua bisa diakses. Kita bisa akses juga secara free di JOHNS HOPKINS UNIVERSITY dan ENCYCLOPEDIA BRITANICA.

Pada Universitas Negeri Padang, tersedia akses pada Proquest, EBSCO dan IET. Pada Proquest, http : //search.proquest.com, dengan username : 08wgm8377g dan password : PQUNP\#1padang. Kemudian, IET digital Library (The Institution of Engineering and Technology), dengan URL : http ://www.ietdl.org. Terakhir, pada EBSCO dengan alamatnya http://search.ebscohost.com/ ; http://m.ebscohost.com; http://search.ebscohost.mobi, dengan Username : ns180943 dan Password : password.

\section{HASIL DAN PEMBAHASAN} INSTALASI ENDNOTE

Endnote adalah sebuah software yang dikembangkan oleh Thomas Reuters. Dimana fungsi-fungsi endnote diantaranya, yaitu :

a. Searching Online Database

b. References and Images Database

c. Bibiliography and Manuscript maker 
Bagaimana menginstall aplikasi EndNote pada Windows 8?. Sebelum kita menginstall aplikasi EndNote ada beberapa hal yang harus dilakukan dan diketahui, diantaranya :

- $\quad$ Tidak terkoneksi dengan jaringan Internet

- $\quad$ Office dalam keadaan close (tidak sedang digunakan ketika ingin menginstall aplikasi EndNote)

- $\quad$ Endnote hanya terintegrasi di Microsoft Word Office

Oke, langsung saja kita mulai langkah menginstall aplikasi EndNote.

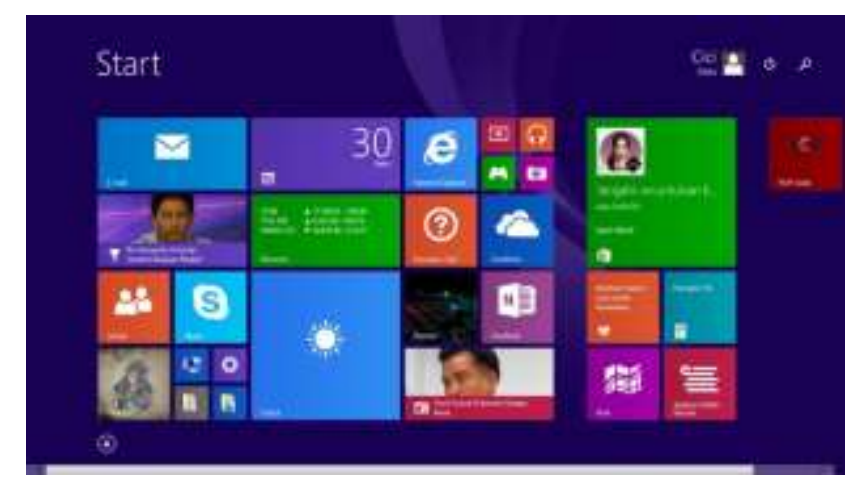

Gambar 4. Tampilan awal Windows 8

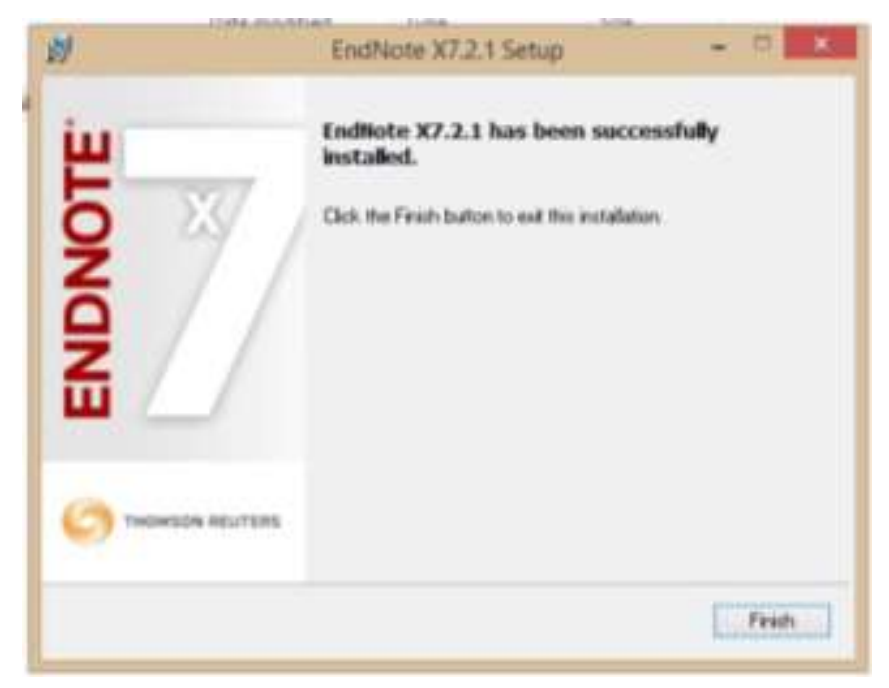

Gambar 5. Tampilan Setelah Proses Instalasi

\section{Penggunaan Endnote X7(1-22)}

Software Endnote X7 dikeluarkan oleh Thomson Reuters untuk kepentingan scientist di seluruh dunia, sejak tahun 1988-2013. Pengembangan software adalah PDFTron System Inc, dan didistribusikan Thomson Reuters dibawah lisensi. Software ini diaplikasikan untuk Penjelajah Literatur dan Jurnal jurnal yang terindex, Pembuatan Library Digital dan Penyusunan Literatur sesuai standar ilmiah dan internasional, berdasarkan Universitas universitas Ternama di Dunia (Harvard, Vancouver, etc) dan Lembaga keilmuan bereputasi (American Chemical Society/ACS, Acta Biomaterialia, Ann Rev Biophysics, etc).

Pembuatan library digital dilakukan dengan menentukan nama library, bisa berdasarkan nama personal, atau berdasarkan objek kajian/bahasan. Library bila dibuat dalam skala besar dilakukan untuk 
Main Topik, misalnya mata kuliah. Jika dilakukan untuk tujuan paper, maka library sesuai dengan tematik paper yang dibuat. Secara sederhana, pada BAR, pilih NEW, lalu masukkan NAMA LIBRARY yang diinginkan, dan PILIH LOKASI atau FOLDER sesuai dengan penyimpanan data.

Penjelajahan literasi menggunakan endnote X7, dapat dilakukan dengan menentukan perpustakaan yang akses. Beberapa Universitas besar dan ternama di dunia, tidak memberikan akses kecuali bagi mahasiswa mereka sendiri atau pihak lain yang diberikan lisensi berupa Username dan password. Universitas Oxford di Inggris, Universitas Adelaide, dan beberapa universitas di Amerika Serikat tidak menyediakan akses kepada pengguna luar seperti pada gambar 6. Akses koneksi ini membutuhkan jaringan internet dan izin koneksi internal pada Perpustakaan Dunia yang akan diakses. Akses yang cukup memadai dapat dilakukan pada Universitas Johns Hopkins, di Baltimore, Maryland, Amerika Serikat, berdiri sejak 1876. Universitas ini menyediakan akses free bagi penjelajah penjelajah literasi dunia.

Begitu juga Perpustakaan ENCYCLOPEDIA BRITANICA, juga memberikan akses free. Encyclopedia Britanica Inc, merupakan ensiklopedia tertua di dunia yang berada di Inggris, yang dirilis 1768-sekarang. Perpustakaan yang lain adalah Pubmed (NLM) yang menyediakan lebih dari 26 juta manuskrip yang bisa diakses dan didownload untuk membuat perpustakaan personal dan disitasi untuk keperluan pembuatan karya ilmiah dan studi literature ilmiah.

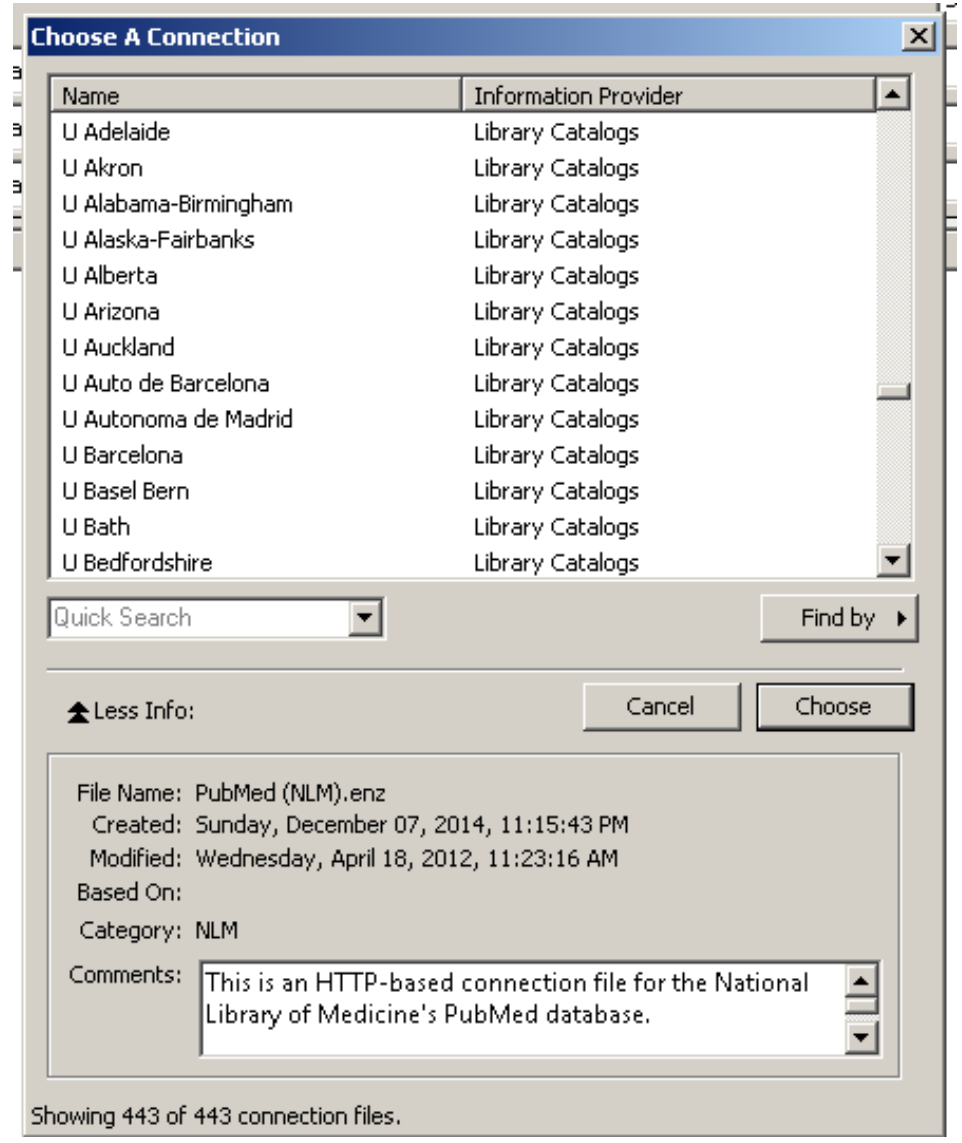

Gambar 6. Beberapa akses yang terblokir pada beberapa Universitas Dunia 
Pembuatan REFERENSI dilakukan dengan mentrasnform atau menyimpan hasil pencarian ke dalam bentuk referensi. Langkah berikutnya adalah melakukan pencarian FULL TEXT dari literature yang digunakan secara otomatis dan tersimpan secara rapi pada LIBRARY yang telah dibuat. Apabila semua file sudah tersimpan, maka untuk membuat REFERENSI atau kutipan pada bagian yang diperlukan dari bahan bahan yang diakses tersebut, koneksi online tidak diperlukan. Pada saat penyusunan artikel atau karya ilmiah, maka akses literature secara terintegrasi tergabung pada MICROSOFT WORD. Hal ini memudahkan untuk menandai bagian bagian Studi PUSTAKA yang dijadikan referensi dari sebuah karya ilmiah seperti terlihat pada gambar 7 .

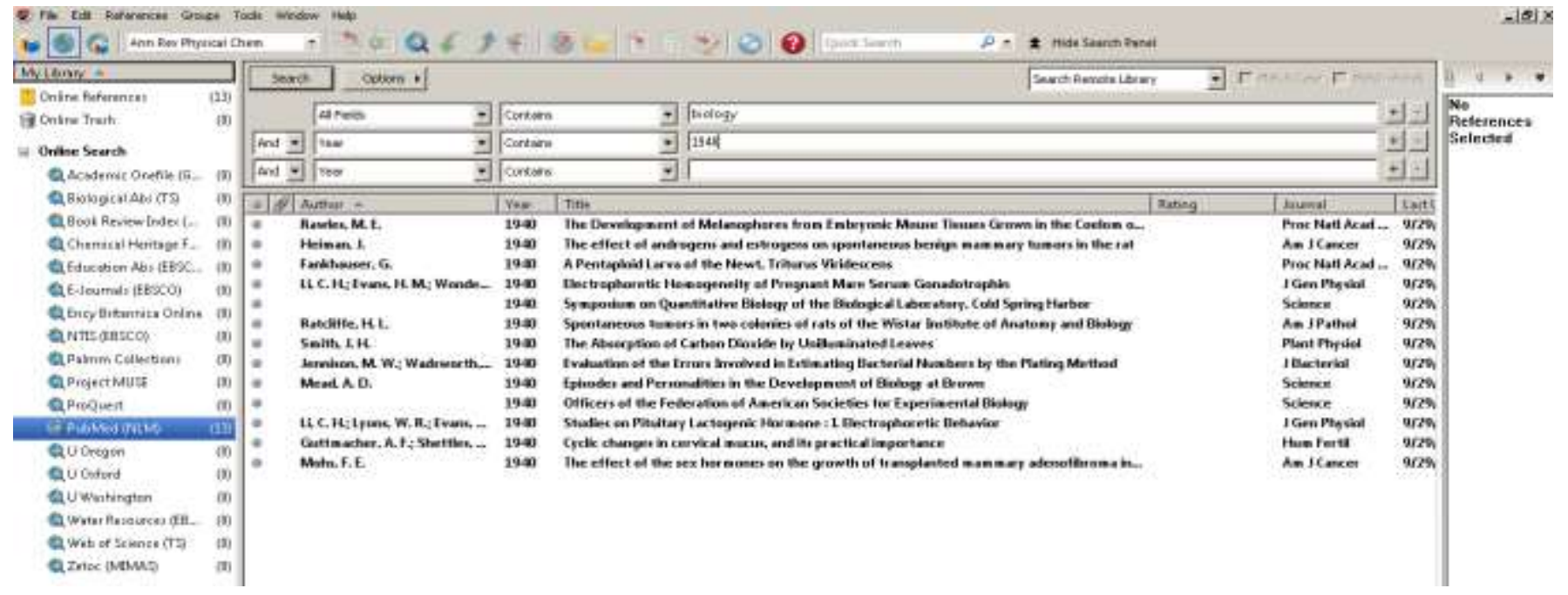

Gambar 7. Penjelajahan Endnote X7 untuk keyword BIOLOGY pada Pubmed

Pada gambar 7 terlihat beberapa kolom yang bisa membantu proses penjelajahan menjadi efisien dan efektif. Pada gambar, proses pencarian dibatasi dengan YEAR atau tahun yakni 1940. Hasilnya adalah pada tahun 1940 terdapat 13 buah manuskrip yang tersimpan pada perpustakaan PubMed yang bisa diakses dan diambil secara gratis. Proses selanjutnya adalah memindahkan atau mengcopy hasil penjelajahan ke dalam LIBRARY personal dengan cara select dengan drag sehingga semua hasil pencarian terwarnai, lalu pada BAR pilih REFERENCES dan COPY REFERENCES TO, pilih NEW (jika belum ada) atau pilih CHOOSE (bila sudah ada). Jika selesai, maka selanjutnya lakukan langkah jelajah FULL TEXT.

Keunggulan ENDNOTE X7 adalah aplikasi ini sudah terintegrasi dengan MICROSOFT WORD, sehingga kutipan yang dilakukan dapat diakses dengan mudah dan penandaannya dilakukan secara otomatis dengan pilihan sebagai berikut. Aktifkan BAR Endnote, lalu buka LIBRARY, dan selanjutnya drag bagian yang akan menjadi kutipan pada ENDNOTE. Pindah Kerja ke MICROSOFT WORD, lalu aktifkan BAR ENDNOTE pada WORD.

Selanjutnya, aktifkan BAR endnote dan tampilan akan berubah seperti gambar 9. Lalu, pilih BAR kiri atas, INSERT CITATION, lalu pilih selected citation, dan tekan ENTER. Maka secara otomatis, citasi akan masuk pada dokumen word yang sedang dibuat.

Proses literasi selesai apabila penyempurnaan dilakukan dengan menggunakan aplikasi pelengkap pembantu yang telah tersedia. Misalnya, google translator untuk penterjemahan literasi, CambridgeSoft untuk display mikroskopik dan simbolik, NITRO 8 untuk konversi dan pengolahan alfabetis, dan snipping tool untuk image dan cuplikan gambar secara cepat dan praktis. 
Proses proses aplikasi pelengkap dapat dilakukan dengan melakukan latihan membuat satu topic bahasan atau kajian ilmiah. Pertama, lakukan pilihan tema, dan buat idea tau gagasan menjadi beberapa kalimat, serta tentukan keyword yang akan dilakukan penelusuran. Setelah itu, proses pengumpulan dan ekplorasi literaratur dilakukan, baik literature berbahasa inggris maupun Indonesia. Namun, karena proses dilakukan secara internasional dan di perpustakaan dunia, maka umumnya naskah yang diperoleh adalah naskah dalam bahasa inggris.

Pada pengolahan data atau literature, peranan aplikasi pembantu sangat dominan, salah satunya adalah Nitro 8 yang berfungsi melakukan konversi PDF menjadi word. Setelah itu, lakukan formatting dan editing sebelum melakukan translating pada Google Translator. Apabila proses formatting dan editing awal atau CLEAN MISSROUTE atau Kesalahan posisi dokumen, baik kata dan kalimat serta tanda baca, maka proses selanjutnya akan keliru. Apabila diperlukan FIND and REPLACE bisa membantu. Setelah semua DOKUMEN KONVERSI selesai dibersihkan, maka lanjutkan dengan translating dan editing. Proses ini memerlukan latihan dan pengulangan, agar didapat pemahaman yang benar dari proses penterjemahan. Sebab, Google Translator bersifat umum, sementara bahan literasi yang akan dipahami lebih spesifik.

Penggunaan E-Learning dan aplikasi lainnya, adalah kemampuan atau skill computer yang tidak sulit, jika kemampuan literasi sudah dipahami dan dilatih. Pada bagian lanjutan adalah konversi WORD to PDF juga diperlukan pada tugas tugas yang harus dikirimkan pada e-learning dari mata kuliah yang dipilih pada setiap semester. Penggunaan e-learning secara spesifik menggunakan data Username dan Password yang sesuai dengan nomor identitas NIM yang passwordnya bisa disesuaikan setelah mengakses perubahan password secara personal.

\section{MODEL PENYUSUNAN KARYA TULIS BERBASIS ONLINE}

Setelah melakukan Analisis, Diagnosa, Develop, maka model penyusunan yang dihasilkan merupakan sebuah siklus berkelanjutan seperti terlihat pada gambar 8. Pada siklus ini Guru dan Akademisi melalui tahapan drafting, lalu menyimpannya di repository dan akhirnya melakukan sitasi dengan data online dan proses ini akan menghasilkan satu data karya ilmiah yang terbackup secara online(23-26).

Tabel 1. Nilai CV sebelum dan setelah pelatihan Model Penulisan Karya Ilmiah

\begin{tabular}{clcccc}
\hline \multirow{2}{*}{ NO } & \multicolumn{1}{c}{ Nama } & \multicolumn{2}{c}{ Sebelum Pelatihan } & \multicolumn{2}{c}{ Setelah Pelatihan } \\
& & Nilai & CV & Nilai & CV \\
\hline 1 & Azizatul Hayat & 80 & & 85 & \\
2 & Nova Nora & 85 & & 90 & \\
3 & Fany Mella & 90 & & 90 & \\
4 & Syukra Hayati & 80 & & 85 & \\
5 & Asnizar & 80 & & 85 & \\
6 & Laily Syaadah & 85 & 2.75 & 85 & 1.53 \\
7 & Adri Desis & 65 & & 85 & \\
& Rahmadiana & 80 & & 85 & \\
8 & Yusra & 90 & & 90 & \\
9 & Raudatul Jannah & 90 & & 80 & \\
10 & Denie Rosali & 60 & & \\
\hline
\end{tabular}

Pada proses pelatihan yang dilakukan pada Guru guru MGMP Kimia Kota Padangpanjang, kemampuan peserta akan dievaluasi dari proses implementasi yang dilakukan selama 4 kali pertemuan. 
Hasilnya diperoleh perubahan secara signifikan seperti terlihat pada tabel 1. Pada hasil pengujian statistik dengan melihat perubahan pada nilai CV (Coeficient of Variations) diperoleh penurunan dari 2.75 menjadi 1.63. Penurunan ini berarti terjadi perubahan dalam kompetensi peserta terhadap cara penulisan karya ilmiah setelah menggunakan model yang diterapkan.

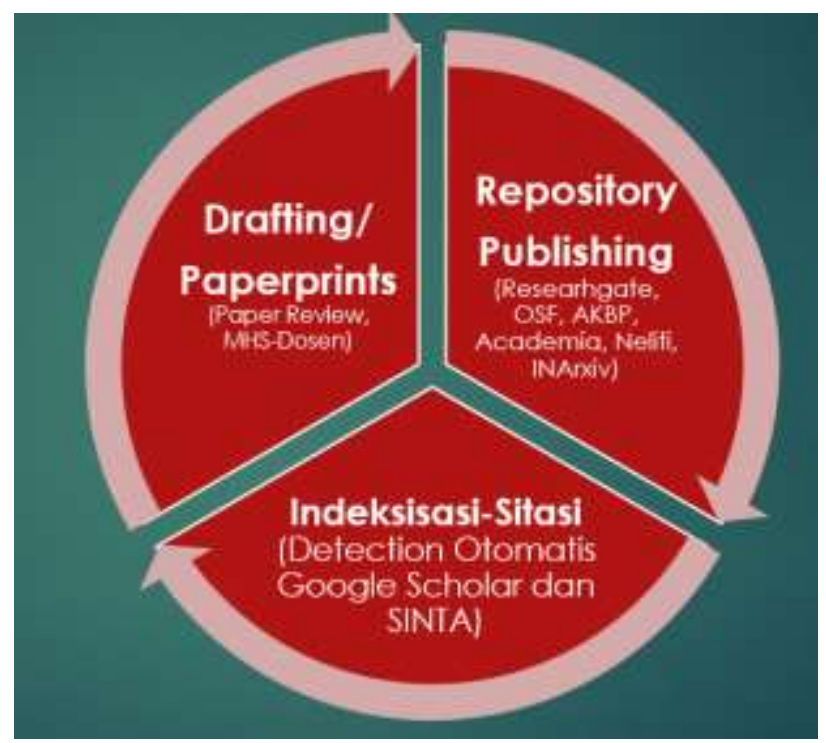

Gambar 8. Model Penyusunan Karya Ilmiah berbasis Data Online

Setelah pengembangan Model berhasil dilakukan, maka kepada peserta diberikan kuisioner berupa angket dengan 10 pernyataan sebagaimana terlihat pada Tabel 2. Analisis terhadap angket menunjukkan hasil yang sangat baik dengan persentase sebagaimana terlihat pada gambar 9. Dalam gambar ini terlihat peningkatan kemampuan peserta (Guru guru MGMP Kimia Kota Padangpanjang) dalam menyusun karya ilmiah berbasis online data dengan menggunakan endnote. Peserta juga memiliki ketertarikan untuk menyusun karya ilmiah dengan menggunakan endnote dengan besarnya persentase $20 \% \mathrm{AS}, 60 \% \mathrm{~S}$ dan $20 \%$ SS.

Tabel 2. Kuesioner Angket Model Penyusunan Karya Ilmiah berbasis Online Data dengan Endnote

\begin{tabular}{|l|l|l|l|l|l|l|l|l|}
\hline No & \multicolumn{1}{|c|}{ Item } & $\begin{array}{c}\text { STS } \\
\text { (1) }\end{array}$ & $\begin{array}{c}\text { TS } \\
\text { (2) }\end{array}$ & $\begin{array}{c}\text { ATS } \\
\text { (3) }\end{array}$ & $\begin{array}{c}\text { N } \\
\text { (4) }\end{array}$ & $\begin{array}{c}\text { AS } \\
\text { (5) }\end{array}$ & $\begin{array}{c}\text { S } \\
\text { (6) }\end{array}$ & $\begin{array}{l}\text { SS } \\
\text { (7) }\end{array}$ \\
\hline 1 & $\begin{array}{l}\text { Aplikasi Endnote dapat memudahkan dalam } \\
\text { mencari literasi atau bahan bacaan. }\end{array}$ & & & & & & & \\
\hline 2 & $\begin{array}{l}\text { Aplikasi Endnote dapat membantu guru dalam } \\
\text { menuliskan daftar pustaka dengan mudah. }\end{array}$ & & & & & & \\
\hline 3 & $\begin{array}{l}\text { Aplikasi Endnote mempermudah guru dalam } \\
\text { mencari literasi yang butuh waktu yang lama. }\end{array}$ & & & & & & \\
\hline 4 & $\begin{array}{l}\text { Aplikasi Endnote membantu guru dalam membuat } \\
\text { kutipan dan daftar pustaka secara otomatis. }\end{array}$ & & & & & & \\
\hline 5 & $\begin{array}{l}\text { Saya memiliki perangkat (laptop/ tablet) untuk } \\
\text { menggunakan aplikasi Endnote. }\end{array}$ & & & & & & \\
\hline 7 & $\begin{array}{l}\text { Di sekolah/kelas terdapat fasilitas untuk menerapkan } \\
\text { Endnote. }\end{array}$ & & & & & \\
\hline
\end{tabular}




\begin{tabular}{|l|l|l|l|l|l|l|l|l|}
\hline 8 & $\begin{array}{l}\text { Saya memiliki akses untuk menggunakan aplikasi } \\
\text { Endnote. }\end{array}$ & & & & & \\
\hline 9 & Saya tertarik untuk menggunakan aplikasi Endnote. & & & & & & & \\
\hline 10 & $\begin{array}{l}\text { Saya akan menggunakan aplikasi Endnote ini untuk } \\
\text { membuat karya tulis ilmiah. }\end{array}$ & & & & & \\
\hline
\end{tabular}

Keterangan : $\mathrm{TS}=$ Sangat Tidak Setuju (1), $\mathrm{TS}=$ Tidak Setuju (2), ATS = Agak Tidak Setuju (3) $\mathrm{N}=$ Netral, antara setuju dan tidak setuju (4), AS = Agak setuju (5), S = Setuju (6) dan SS = Sangat Setuju (7)

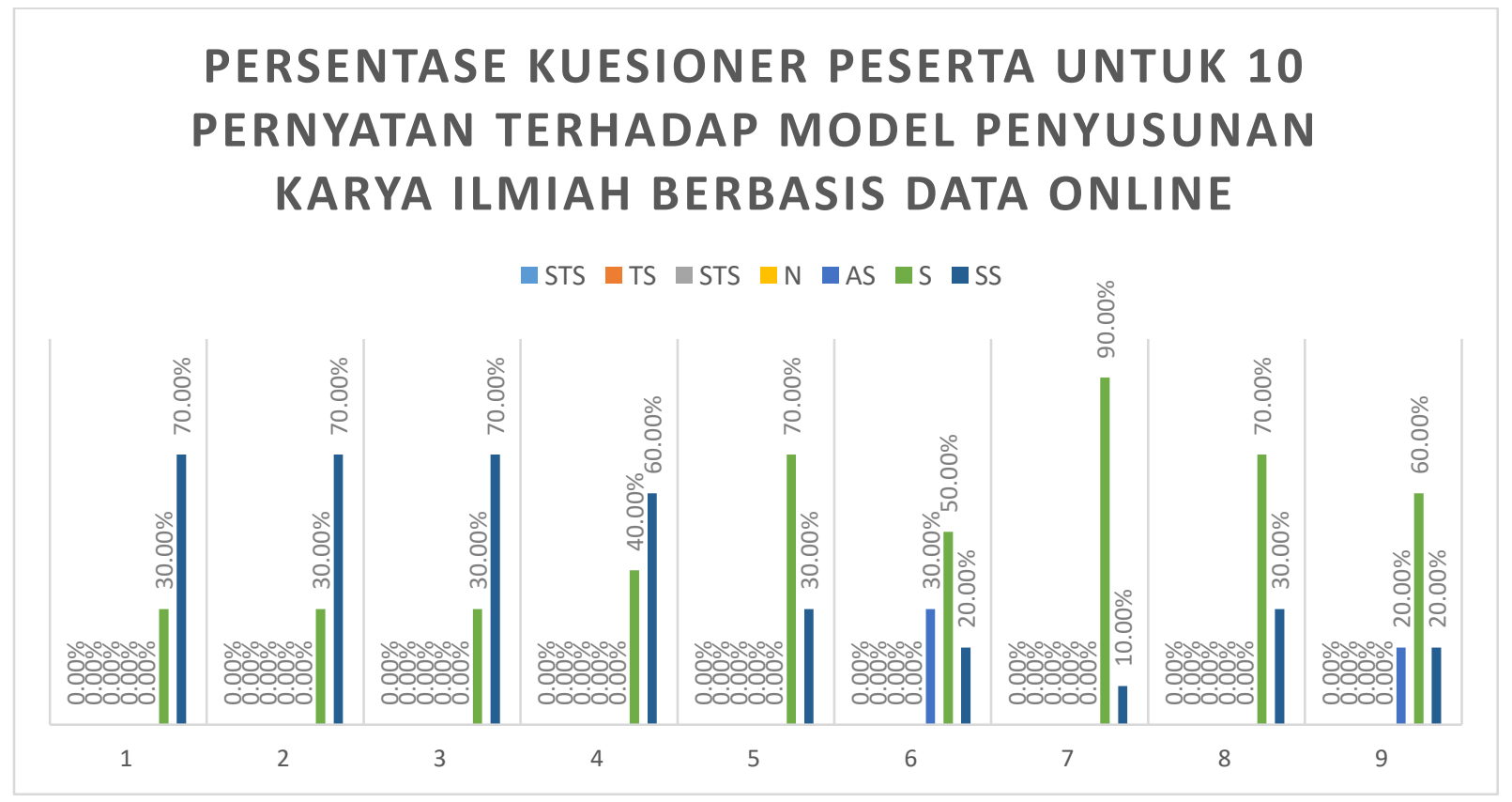

Gambar 9. Persentase angket terhadap Model Penyusunan Karya Ilmiah berbasis online data menggunakan Endnote

\section{KESIMPULAN}

Model penyusunan karya ilmiah berbasis online data dengan menggunakan endnote berhasil dibuat dengan menggunakan metode ADDIE. Model pengembangan diujicobakan dengan pelatihan library online dan penyusunan karya ilmiah bagi guru guru MGMP Kimia Kota Padangpanjang pada 6 kali pertemuan, dalam bentuk 4 kali pelatihan dan 2 kali evaluasi. Pada uji kompetensi untuk melihat penarapan model, dilakukan dengan mengukur koefisien variasi. Nilai CV yang didapatkan mengalami penurunan dari 2.75 $\%$ menjadi $1.63 \%$, yang membuktikan bahwa penerapan model penyusunan karya ilmiah ini berjalan dengan baik dan signifikan. Hasil analisis angket menunjukan persentase yang tinggi terhadap minat yakni $30 \%$ SS dan $70 \% \mathrm{~S}$, dan persentase peserta akan menerapkan model ini dalam penyusunan karya ilmiah mencapai $20 \%$ AS, $60 \%$ S dan $20 \%$ SS.

\section{REFERENCES}

1. Aalai E, Gleghorn C, Webb A, Glover SW. 2009. Health information and libraries journal 26:56-62

2. Altman SH, Shactman D. 1997. The New England journal of medicine 337:1778-9 
3. Bramer WM, Giustini D, de Jonge GB, Holland L, Bekhuis T. 2016. Journal of the Medical Library Association : JMLA 104:240-3

4. Cantor WJ, Brunet F, Ziegler CP, Kiss A, Morrison LJ. 2005. CMAJ : Canadian Medical Association journal $=$ journal de l'Association medicale canadienne 173:1473-81

5. Brooke-Sumner C, Petersen I, Asher L, Mall S, Egbe CO, Lund C. 2015. BMC psychiatry 15:19

6. Escobedo AA, Arencibia R, Vega RL, Rodriguez-Morales AJ, Almirall P, Alfonso M. 2015. Journal of infection in developing countries 9:76-86

7. Einollahi B, Motalebi M, Taghipour M, Ebrahimi M. 2015. Nephro-urology monthly 7:e30911

8. $\quad$ Li Y, Wen J, Du L, Gao Z, Li L, et al. 2009. Journal of evidence-based medicine 2:252-7

9. Jiang Y, Lin C, Meng W, Yu C, Cohen AM, Smalheiser NR. 2014. Database : the journal of biological databases and curation 2014:bat086

10. Lorenzetti DL, Ghali WA. 2013. BMC medical research methodology 13:141

11. Nawafleh N, Hatamleh M, Elshiyab S, Mack F. 2016. Journal of prosthodontics : official journal of the American College of Prosthodontists 25:116-26

12. Ong ME, Mackey KE, Zhang ZC, Tanaka H, Ma MH, et al. 2012. Scandinavian journal of trauma, resuscitation and emergency medicine 20:39

13. Liu X, Wu J, Wang J, Liu X, Zhao S, et al. 2009. Nucleic acids research 37:W33-9

14. Ng L, Pitt V, Huckvale K, Clavisi O, Turner T, et al. 2014. Systematic reviews 3:121

15. Rathbone J, Carter M, Hoffmann T, Glasziou P. 2015. Systematic reviews 4:6

16. Roura M, Domingo A, Leyva-Moral JM, Pool R. 2015. BMC public health 15:472

17. Shayo A, Buza J, Ishengoma DS. 2015. Malaria journal 14:135

18. van der Heijden E, Lopes AD, Bryant A, Bekkers R, Galaal K. 2015. The Cochrane database of systematic reviews 1:CD010757

19. Verbitskaya EV. 2015. The International journal of risk \& safety in medicine 27 Suppl 1:S89-90

20. Wei M, He Y, Wang J, Chen N, Zhou Z, Wang Z. 2014. PloS one 9:e87461

21. Wickramasinghe DP, Perera CS, Senarathna S, Samarasekera DN. 2013. BMC medical education 13:175

22. Younger P, Boddy K. 2009. Health information and libraries journal 26:126-35

23. H., Azhar, M., \& Zainul, R. (2018, April 9). THE EFFECTIVENESS OF STRUCTURED INQUIRY BASED MODULE TO IMPROVE MENTAL MODEL OF CONCEPT MOLE. https://doi.org/10.31227/osf.io/ckjtb

24. Guci, S. R. F., Zainul, R., \& Azhar, M. (2017, November 15). PENGEMBANGAN MEDIA PEMBELAJARAN BERBASIS TIGA LEVEL REPRESENTASI MENGGUNAKAN PREZI PADA MATERI KESETIMBANGAN KIMIA KELAS XI SMA/MA. https://doi.org/10.31227/osf.io/n7jkf

25. Zainul, R., Oktavia, B., G., \& putra, a. (2017, November 10). Pengenalan Dan Pengembangan E-Modul Bagi Guru- Guru Anggota MGMP Kimia Dan Biologi Kota Padang Panjang. https://doi.org/10.31227/osf.io/yhau2

26. Zainul, R. (2016, October 2). Studi Literasi Menggunakan Endnote Dan Aplikasi Pembantu (Google Translator, Google Cendikia, Google Sites, Chemoffice 2008, e-learning, dan Snipping Tool). https://doi.org/10.31227/osf.io/5ncpe 